\title{
ORANG MELAYU DI KOTA TERNATE ABAD XV-XIV
}

\section{The Malay People in Ternate Town in XV-XIVth Century}

\author{
Usman Nomay \\ Sekolah Tinggi Agama Islam Negeri Ternate \\ Jl. Dufa-Dufa Pantai Ternate Maluku Utara \\ Email: Usman.nomay@gmail.com
}

Naskah diterima tanggal 9 Mei 2014. Naskah direvisi tanggal 30 Mei 2014. Naskah disetujui tanggal 6 Juni 2014

\begin{abstract}
Abstrak
Penelitian ini dimaksudkan untuk mengungkapkan sejarah orang Melayu di Kota Ternate, kedatangan orang Melayu, dan peranan orang Melayu pada abad 15-16. Metode yang dipakai dalam mendapatkan data adalah metode sejarah, yang terdiri atas; heuristik, kritik, interpretasi dan historiografi. Setelah heuristik maka tahap yang kedua adalah kritik atas data yang telah diperoleh. Apakah data tersebut perlu dipakai dan cocok dengan topik yang sedang diteliti atau tidak. Tahapan berikutnya adalah interpertasi. Tahap ini dimaksudkan agar tidak terjadi penerimaan data mentah, tetapi harus ada interpertasi atas data yang telah ditemukan. Kemudian tahapan yang terakhir adalah penulisan atas data yang sudah dianggap valid. Rempah-rempah sebagai komoditi utama yang menjadi salah satu penyebab kehadiraan orang Melayu ke Ternate. Rempah-rempah dibeli dengan harga yang murah di Ternate, dan dijual di wilayah lain akan mendatangkan keuntungan berlipat ganda. Nahkoda Ismail sebagai orang Melayu yang datang dan pergi dari Malaka ke Ternate untuk membawa pedagang Melayu untuk membeli rempahrempah. Bukti yang masih terlihat hingga sekarang adalah Benteng Gamlamo atau Benteng Orangje. Yang mana benteng ini pernah menjadi gudang penyimpanan barang dagangan orang Melayu. Datuk Maula Husain, orang Melayu yang sangat berperan dalam proses masuk dan berkembangnya Islam di Ternate. Beliau mempunyai suara yang merdu dalam membaca al-Quran sehingga orang Ternate ingin untuk mengikutinya, dan diundang oleh sultan Ternate untuk mengajarkan baca-tulis al-Quran kepada orang-orang yang ada di kesultanan Ternate. Masjid kesultanan Ternate awalnya berada di kampung Melayu, namun setelah itu dipindahkan ke tempat yang sekarang.
\end{abstract}

Kata kunci: orang Melayu, islamisasi, Ternate

\begin{abstract}
This research meants to express the history of Malay people in Ternate Town, the coming of Malay people in Ternate Town, and the role of Malay people in Ternate Town in XV and XVIth century. The research method used history research method for getting the data consist of heuristic,critical,interpretation and historiography. After heuristic, the second step is criticism to the data which had been obtained. What the data require to be used and to correct with the topic that is being checked or not. The next step is interpretation. This step meants in the hope that there is not to be happened by the acceptance of incomplete data, but there is supposed to be interpretation to the data which have been found. And then the last step is writing to the data that had been considered. Spices as especially commodity becoming one cause Malay people to Ternate. Spices bought at the price of cheap in Ternate, and sold in the other region hence will get the coin money. Ismail who was sailor as incoming from Malaka and going to Ternate for bringing the Malay traders to buy the spices. One of evidence which still was seen until now is the existence fortress of Gamlamo or fortress Orangje. Which this fortress had become the stowage of malay people merchanidise. Maula Husain who was Malay people playing a part in entering process and expanding Islam in Ternate. He has the golden voice when he was reading al-Quran so that Ternate people want to follow him. He had been invited by sultan Ternate for teaching a reading and writing al-Quran to people in Ternate's sultanate. The mosque of Ternate's sultanate hitherto still exists and becomes the icon of Ternate's sultanate. The mosque of Ternate's Sultanate initially was in Malay village, whereas that the mosque had been moved to a new place until right now.
\end{abstract}

Keywords : Malay people, islamization, Ternate 


\section{PENDAHULUAN}

$\mathrm{N}$ usantara dihuni oleh ras manusia yang menarik dan istimewa, yaitu ras Melayu, yang tak dapat ditemui di luar jajaran kepulauan tersebut. Karena alasan tersebut gugusan pulau ini disebut Kepulauan Nusantara (Wallace, 2009:1). Ternate sebagai bandar Jalur Sutera adalah merupakan sebuah peristiwa sejarah yang di dalamnya menggambarkan sebuah kota yang tersentuh oleh sebuah peradaban sejak ribuan tahun yang lalu. Jauh sebelum datangnya bangsa Eropa (Spanyol, Portugis, dan Inggris) di penghujung abad ke 14. Pedagang-pedagang Cina pada zaman Dinasti Han (206 SM-200M) dan Dinasti Tang (1618-1906) berdasarkan perjalanan mereka menyebutkan suatu pulau penghasil rempah-rempah yang bernama $\mathrm{Mi}$ $L i-K u$, kepulauan yang tidak lain adalah Maluku.

Ternate menjadi tempat rempah-rempah diketahui oleh para pedagang Melayu. Melalui kemahiran akan pengetahuan agama Islam orang Melayu menjalankan fungsi ganda ketika berada di Ternate. Fungsi tersebut adalah berdagang sambil mendakwahkan Islam. Dengan kemampuan mendakwahkan Islam kepada masyarakat di Ternate yang kala itu masih terikat dengan kepercayaan terhadap roh-roh atau animisme. Olehnya itu, penelitian ini dimaksudkan untuk mengetahui seberapa besar pengaruh yang dilakukan oleh orang Melayu terhadap masyarakat Ternate.

Dengan berlabuhnya kapal dagangan Arab, dan Melayu inilah, pengetahuan orang Portugis akan asal sumber rempah-rempah telah diketahui olehnya, melalui pengetahuan akan jalur ke kepulauan rempah-rempah (Spice Roads) itu Portugis bergegas menuju ke Ternate. Nahkoda Ismail, seorang pedagang Melayu, yang mempunyai banyak pengetahuan pelayaran ke Maluku pada umumnya dan Ternate khususnya, diminta menjadi pilot atau pemandu ekspedisi Portugis. Ismail menggunakan jung China sebagai kapal pemandu, yang berlayar paling depan menuntun tiga buah kapal Portugis pimpinan d'Abreau (Amal, 2010:23). Perjalanan yang dipandu oleh nahkoda Ismail itu akhirnya sampai ke Maluku.

Berdasarkan beberapa fakta awal yang telah diungkapkan di atas, maka rumusan masalah yang diangkat dalam penelitian tentang orang Melayu di Ternate pada abad 15-16 adalah bagaimana proses kedatangan dan kehadiran orang Melayu di Kota Ternate dan bagaimana peranan orang Melayu di Kota Ternate Pada Abad 15-16. Tujuan penelitian ini dimaksudkan untuk mengetahui proses kehadiran dan kedatangan orang Melayu di Kota Ternate, dan untuk mengetahui bagaimana peranan orang Melayu di Kota Ternate pada abad 15-16. Sementara kegunaan penelitian ini adalah dari sisi teoritis, penelitian ini diharapkan dapat mengetahui proses kedatangan orang Melayu ke Kota Ternate. Kemudian penelitian ini juga diharapkan dapat memberikan, dan menemukan teori-teori baru tentang peranan orang Melayu dalam perdagangan di Kota Ternate khususnya. Kegunaan praktis, yakni diharapkan penelitian ini dapat menjadi acuan bagi pemegang kebijakan dalam rangka memperat hubungan antar suku, ras etnis dan golongan di Ternate, menjadi bahan acuan bagi penulis lain yang ingin menulis tentang orang Melayu, Arab, atau orang China di Ternate, dalam fokus kajian yang lain pada abad yang lain.

Banyak kajian tentang kemelayuan yang telah dilakukan di Indonesia baik yang sudah terbit dalam bentuk buku maupun dalam tulisan jurnaljurnal ilmiah. Untuk kepentingan penelitian ini, beberapa teori yang berkaitan dengan kemelayuan perlu diangkat agar terjadi perbedaan tentang kemelayuan yang telah tertulis dengan fokus penelitian ini.

Urbanisasi dan adaptasi peranan misi budaya Minangkabau dan Mandailing, buku yang ditulis oleh Usman Pelly ini pada bab III menulis tentang etnik Melayu dan peranannya. Pokok pembahasan yang dibahas olehnya tentang peranan seorang sultan Melayu yang berperan ganda dalam sebuah masyarakat. Sultan Melayu selain sebagai kepala Negara juga berperan sebagai penghulu adat dan ulil amri (pelindung orang beriman). Fungsi ulil amri sehari-hari dilaksanakan penting dalam birokrasi kemelayuan, tetapi kebanyakan tidak dipegang oleh Melayu asli, melainkan oleh Melayu pendatang (Pelly, 2004:51).

Djohan Hanafiah dengan judul Melayu-Jawa citra budaya dan sejarah Palembang. Pada bab III poin e dijelaskan tentang Geneologi Elite MelayuJawa. Elite Melayu-Jawa memerlukan asal-usulnya, sehingga sumber kharisma yang memberikan "tuah" (Melayu) atau pulung (Jawa), ternyata mempunyai nilai kekharismaan yang sama (1995:66). Orang Melayu di kota Makassar abad XVII. Buku ini lebih melihat tentang faktor perdagangan yang merupakan motifasi utama kedatangan orang Melayu ke Makassar pada abad itu. Inti teori yang diungkapkan dalam buku itu bahwa perkembangan jaringan perdagangan orang Melayu bertumpuh 
pada semangat progresif, yang hampir dipraktekkan oleh semua pedagang Melayu (Nomay, 2009:31).

Kemudian, buku lain yang ditulis oleh $\mathrm{H}$. M. Lah Husny dengan judul "Lintasan sejarah peradaban dan budaya penduduk Melayu-Pesisir Deli Sumatera Timur, 1612-1950. Teori-teori yang dikajinya antara lain tentang implementasi kebudayaan Melayu, dan siapa sajakah manusia Melayu itu.

Olehnya itu, dapat diberikan sebuah catatan bahwa yang disebut orang Melayu dalam penelitian ini adalah orang-orang Melayu yang datang dari beberapa daerah di Indonesia serta luar Indonesia dengan menekuni perdagangan sebagai aktifitas keseharian dan beragama Islam. Karena dagang dan Islam merupakan entri point bagi orang Melayu, kehadiran nahkoda Ismail dan Datu Maula/Maulana Husein di Ternate pada abad ke 15-16 mempunyai manfaat tentang pola islamisasi masyarakat Ternate hingga sekarang.

\section{METODE PENELITIAN}

Proses pecarian data tentang orang Melayu di Ternate pada abad 15-16 dilakukan dengan dua cara. Pertama dengan menelaah buku-buku yang membahas tentang orang Melayu. Selain buku, informasi tentang peranan mereka dalam pembangunan masjid pertama di Ternate di masa itu melalui hasil-hasil penelitian. Misalnya hasil penelitian tentang masjid kesultanan Ternate. Kedua adalah dengan cara mewawancarai sejarahwan Ternate yang dianggap sangat kompeten dalam sejarah Maluku, Ternate, Tidore dan Jailolo. M. Adnan Amal adalah sejarawan yang selain bukubukunya, namun juga karena beliau masih hidup sehingga data wawancara sangat banyak didapat beliau.

\section{PEMBAHASAN \\ Kedatangan Pedagang Melayu}

Para ahli sejarah sepakat, semua ekspedisi yang dikirim Portugis dan Spanyol ke Maluku bertumpu pada satu tujuan: menguasai perdagangan rempah-rempah Maluku. Karena perlombaan menemukan Maluku sarat dengan motif ekonomi, sejumlah tantangan menghadang dan mereka harus memutar otak mencari solusi dan meresponnya. Dari perjalanan sejarah, berbagai tantangan dan konflik tersebut dapat dikelompokkan ke dalam dua bentuk: Pertama, persaingan ketat Portugis Spanyol menyebabkan beberapa perjanjian yang disepakati keduanya tidak ditaati dan berakhir dengan konflik yang berkepanjangan. Kedua, tantangan para raja lokal, terutama bagi Portugis, berkenaan dengan sistem yang dibangunnya baik dalam perdagangan, politik, maupun konversi agama (Amal: 2009:353).

Jaringan perdagangan orang Melayu terbentuk ketika koneksitas "dunia Asia" terdesak oleh upaya kolonisasi Portugis di Malaka sejak tahun 1511. Pendudukan Portugis atas Semenanjung Malaka telah mendorong pedagang-pedagang Melayu untuk melakukan eksodus besar-besaran, mencari dunia baru ke kawasan utara, selatan dan belahan timur Nusantara. Penyebaran orang Melayu ke wilayah-wilayah tersebut termotivasi oleh harapan untuk dapat mengembangkan jaringan perdagangan dengan komunitas lain serta penguasa-penguasa setempat dan mendapat tempat yang nyaman dari interfensi Portugis.

Selain menjadi pemandu Nahkoda Ismail juga merupakan seorang pedagang ulung yang memiliki pengetahuan tentang perdagangan rempah-rempah di Ternate. Dalam aktifitasnya Ismail bukan saja membeli rempah-rempah, tetapi terjadi pertukaran barang-dengan pakaian (barter). Karena keuntungannya yang berlipat ganda, Ismail juga mengisi junknya dengan rempah-rempah, kemudian berlayar menuju ke Hitu di Ambon untuk kemudian kembali ke Malaka melalui Gresik.

Ada yang mengatakan bahwa pengunjung pertama Ternate adalah orang Cina, tetapi ada pula yang mengklaim adalah orang Melayu dan Jawa. Keterangan ini berbeda-beda dan tak ada yang dapat memberikan informasi yang pasti. Galvao sepertinya lebih cenderung kepada orang Cina, sebab mata uang yang beredar di Ternate kala itu adalah mata uang Cina, yang disebut fang. Dalam bahasa lokal Ternate sekarang, kata fang selalu bermakna membayar atau bayar. Tidak sampai dua tahun setelah kedatangan Serrao di Ternate, Sultan Bayanullah memberikan hak monopoli perdagangan rempah-rempah kepada Portugis. Syahril Muhammad, ada dua alasan yang menjadi dasar pemberian hak tersebut; pertama, untuk meningkatkan kemakmuran rakyat dan pendapatan kerajaan, karena Portugis bersedia membayar dengan harga yang lebih mahal ketimbang para pedagang Jawa, Arab dan Melayui. Kedua, untuk membangun power bagi kerajaan Ternate dalam persaingannya dengan kerajaan-kerajaan lain di Maluku. Sebab, mempunyai mitra asing dipandang lebih kuat dan lebih handal ketimbang mitra lokal, karena mitra asing Portugis itu memiliki persenjataan modern, seperti bedil, meriam dan kanon (Amal, 2009:25). 
Dengan demikian dapat dikatakan bahwa, jauh sebelum kedatangan orang Eropa kemungkinan telah banyak para pedagang Melayu sudah melakukan kontak interaksi peragangan dengan orang Ternate. Bukti penguasaan orangorang Portugis atas benteng yang dimiliki oleh para pedagang Melayu itu sampai kini masih terlihat. Walaupun telah dirubah bentuknya ke bentuk sebuah benteng sebagimana yang dipahami sekarang. Wujudnya yang sebenarnya sebagai sebuah gudang sudah tidak terlihat lagi.

Berdasarkan beberapa keterangan di atas, maka penting untuk diteliti, terutama berkaitan dengan kedatangan orang Melayu ke Ternate. Ketika orang Melayu datang ke Ternate apa saja yang menjadi peran orang Melayu di abad ke 15 dan 16.

\section{Proses Kedatangan Orang Melayu di Ternate}

Bernard HM Viekke dalam Nusantara a History of Indonesia, yang dikutip oleh Rinto Taib, disebutkan bahwa sejak abad ke-10 telah ada struktur negara yang modern di kawasan Moloku Kie Raha. Semua ini terjadi karena relasi multi etnik akibat jalinan perdagangan rempah-rempah yang terbentuk jauh sebelum era Kristus (global touch). Rute inilah yang kemudian oleh Baron Verdinand Van Richthoven disebut sebagai silk road (jalur sutera). Karena faktor rempah-rempah dari kepulauan Ternate yang dominan dalam rute perdagangan ini. Hanya kata sutra digunakan sebagai metafora atas kehalusan budi pekerti yang terjalin antara hubungan manusia dari berbagai bangsa. Sedangkan menurut A. de, Ciercq bahwa di abad ke-10 di Ternate telah ada pemukiman orang Melayu (Diense, 2008:xv).

Kedatangan orang Melayu ke Ternate bila ditelusuri berdasarkan data-data yang ditemukan ternyata bervariasi. Hal ini diakibatkan karena peranan dari orang Melayu itu sendiri. Kemudian di sisi yang lain adalah penamaan dan klasifikasi pun berbeda terhadap orang Malayu. Untuk mempermudah pengetahuan tentang proses kedatangan orang Melayu ke Ternate, maka peneliti akan menyampaikan data-data tentang kehadiran orang Melayu ke Ternate dalam tiga kategori.

Pertama; cerita rakyat setempat tentang kehadiran seseorang yang bernama Jafar Sadiq atau Jafar Nuh. Konon bahwa dengan menumpang kapal para pedagang Cina, Jafar Sadiq tiba di Ternate pada hari Senin 6 Muharam $643 \mathrm{H}$ tahun 1250. Kehadirannya tepat di pantai Rua. Tidak digambarkan apa yang menjadi tujuan utama kedatangannya, hanya saja bahwa saat tiba di Ternate lalu Jafar Sadiq menikah dengan seorang puteri Ternate yang bernama Nur Sifa. Tetapi apakah nama Islam dari puteri ini adalah merupakan nama dari seorang puteri Melayu pun tidak diceritakan. Hanya saja catatan yang dikemukakan oleh Valentinj bahwa dimasa pemerintahan raja Ternate yang bernama Comala atau Etsilli Naay (1304-1317), di Ternate telah ada orang Jawa dan Melayu, yang mana ibu dari raja Ternate itu ternyata orang Melayu.

Kedua; adalah catatan yang dikemukakan oleh Adnan Amal, bahwa setelah orang Negroid maka datang dua gelombang orang Melayu, yakni doutro dan proto seperti telah disebutkan di atas. Hanya saja keterangan tentang kedatangan orang Negroid itu kapan dan apa aktifitas mereka tidak diketahui. Sehingga agak sulit untuk menentukan proses kedatangan dua prototipe orang Melayu ini dan apa penyebab kedatangannya ke Ternate. Dalam keterangan catatan itu bahwa ketika datangnya orang Melayu proto di Ternate, maka orang Melayu doutro tereliminasikan. Lagi-lagi tidak ada keterangan tentang hal ini.

Ketiga adalah datangnya seorang pedagang Melayu dari Bukittingi untuk membeli rempahrempah sekaligus berdagang. Datuk Maula Husain, merupakan orang Melayu yang banyak sekali mempunyai peranan dalam memberikan pengetahuan Islam kepada penduduk Ternate.

Alfred Russel Wallace, menceritakan kisah perjalanannya ke pulau Makian, salah satu pulau di Molucca (Ternate) pada tahun 1646 "merekah" karena sebuah letusan dahsyat sehingga terbentuk sebuah jurang di satu sisi pulau yang memanjang sampai ke jantung gunung itu. Mengutip bahasanya "ketika saya mengunjungi pulau Makian pada tahun 1860, gunung di pulau itu ditumbuhi hutan sampai ke puncak dan terdapat 12 suku kampung Melayu (Wallace, 2009:4). Walaupun keterangan dari Wallace ini sangat berbeda hampir tiga abad dengan waktu pada penelitian ini, tetapi paling tidak menjadi sebuah keterangan tambahan tentang betapa banyaknya orang Melayu di Ternate.

\section{Peran Orang Melayu di Ternate Abad XV-XIV}

Tentang bagaimana peranan orang Melayu di Kota Ternate pada abad ke 15-16 tentunya dibarengi dengan proses kedatang agama Islam. Karena kebanyakan pedagang Melayu yang datang ke Kota Ternate beragama Islam. Olehnya itu, untuk menelusuri peran orang Melayu, maka tentu masuk dan berkembangnya agama Islam di Ternate pun menjadi sasaran penelitian. 
Tentang masuknya agama Islam di kota Ternate, terdapat beberapa keterangan. Ada keterangan bahwa pada abad ke 13 di Maluku sudah berdiri kerajaan Ternate yang ibu kotanya terletak di Sampalu, (pulau Ternate). Selain kerajaan Ternate, di Maluku juga telah berdiri kerajaan-kerajaan lain seperti kerajaan Jailolo, Tidore dan Bacan. Di antara kerajaan-kerajaan itu, kerajaan Ternate yang paling maju.

Dari penulis-penulis Barat menjelaskan bahwa agama Islam masuk ke Ternate, pada paruh kedua abad ke-15. Tome Pires yang menulis catatan perjalanannya antara tahun (1521-1515) mengatakan bahwa agama Islam telah terdapat di Maluku sekitar lima puluh tahun yang lalu. Antonio Galvao yang pernah menjadi kepala orang Portugis di Ternate (1536-1539) dan pengalamannya itu telah dicatat dalam Histoa das Molucas (1544), menyatakan bahwa Islam telah masuk ke kepulauan ini delapan puluh tahun yang lalu. Antonio Pegafetta yang tiba di Tidore pada tahun 1521, menyebutkan bahwa orang-orang Islam itu telah ada di Maluku kira-kira lima puluh tahun yang lalu.

Ada yang mengatakan bahwa agama Islam masuk di kota Ternate di bawah oleh empat orang syeh dari Irak, yaitu syeh Mansur, syeh Yakub, syeh Umar dan syeh Amin. Dan keempat orang syeh inilah yang menyiarkan agama Islam di kota Ternate dan di pulau Halmahera dan sekitarnya. Hanya saja tidak diberikan keterangan tentang bagaimana proses yang dilakukan dalam menyampaikan ajaran Islam ke penduduk Ternate.

Ada juga yang mengaitkan dengan kehadiran Jafar Sadiq atau Jafar Nur, yang tiba di Ternate pada hari Senin tanggal 6 Muharam $643 \mathrm{H}$ atau $1250 \mathrm{M}$ dan menikah dengan seorang puteri setempat yang bernama Nur Sifa. Jika alasan ini dipakai sebagai awal-mula kedatangan orang Islam ke Ternate, maka Jafar Sadiq adalah orang yang pertama, dan ini diperkirakan sekitar abad ke 13.

Berkaitan dengan lahirnya kota Ternate, dapat dikatakan bahwa pada tahun 1304 telah bermukimnya saudagar dari Jawa dan Sumatera di kampung Melayu. Tentang kampung Melayu, ketika peneliti wawancara dengan sejarawan Ternate; Adnan Amal, beliau katakan bahwa kampung Melayu dulu terletak di kelurahan Santiong sekarang (depan Ternate Mall). Ini berarti bahwa komunitas orang Melayu memang jauh sebelum itu telah ada di Ternate. Hanya saja peran aktifnya dalam penyebaran Islam belum berlaku secara terbuka. Mungkin awalnya komunitas Melayu tinggal di kawasan dua kelurahan ini, Karena antara kelurahan Gamalama tempat beradanya Benteng Gamlamo (Fort Orangje) dengan kelurahan kampung Makassar sangat berdekatan. Dan kemungkinan sering terjadi kontak dagang antara pedagang Melayu dengan pedagang Makassar yang berada di kelurahan di mana sekarang masjid anNur (sigi cim). Mungkinkah masjid an-Nur (sigi cim) ini adalah merupakan awal mulanya berdiri masjid kesultanan yang merupakan karya dari orang Melayu. Sebab ketika peneliti melakukan wawancara dengan Raden Samsudin Bahtiar; warga keturunan Melayu asal Palembang, mengatakan bahwa dahulu wilayah pasar Gamalama adalah tempat bermukimnya orang Melayu asal Palembang. Sering disebut dengan kampung Melayu. Namun sekarang tempat itu tidak lagi menjadi perkampungan orang Melayu dan telah banyak berdomisili oleh pedagang Cina dan Arab, serta sudah menjadi pusat kota dagang Ternate.

Menjelang beberapa puluh tahun kemudian, sebelum masa pemerintahan ayah dari Sultan Zainal Abidin Syah yang biasa disebut sebagai Kolana Gapi Baguna yang memerintah dari tahun 1465-1480 datang seorang pedagang dari pulau Sumatera (Bukitinggi) yang bernama Datuk Maulana Husain. Karena Datuk Maulana Husain mempunyai kelebihan dalam menulis ayat-ayat al-Quran dengan huruf yang indah (kaligrafi), sehingga raja dan keluarganya ingin untuk belajar menulis tulisan indah yang ditulisnya. Kemudian Datuk Maula Husain menyampaikan bahwa sebaiknya bukan saja belajar menulis tulisan indah al-Quran tetapi belajar juga tentang Islam. Dengan cara demikian banyak penduduk Ternate yang mengikuti dan mendalami Islam (Abdulrahman, 2001:21).

Francois Falentijn memberitakan masuknya Islam di Ternate pada tahun 1465 bertepatan dengan mulainya Datu Maula Husain, seorang pedagang Melayu dan dai' Islam melakukan kegiatan dakwahnya (Ahmad, 2000:16). Datuk Maula Husain yang menunjukan jalan kepada sulatan Zainal Abidin Syah untuk menutut ilmu agama Islam di Sunan Giri, (Ambari, 1998:63). Penulis Belanda dan Portugis yang menentukan masuknya agama Islam di Ternate pada tahun 1468 berdasarkan tarikh yang dikaitkan dengan dinobatkannya sultan Zainal Abidin Syah sebagai sultan Ternate.

Datu Maula Husain, adalah seorang Muslim yang berpengetahuan Islam yang luas. Pada waktu-waktu senggang terutama di malam hari ia membaca al-Quran dengan tilawah yang merdu. 
Orang Ternate yang mendengar tilawahnya sangat tertarik dan jumlah pengagumnya makin lamamakin bertambah banyak. Mula-mula mereka hanya mengagumi suara merdu Datu Maula Husain, tetapi makin lama timbul kesan dan keinginan untuk belajar agar mereka juga dapat membaca al-Quran dengan tilawah seperti yang dilakukan oleh Datu Maula Husein.

Beberapa di antara pribumi Ternate itu menemui Datu Maula Husain dan mengemukakan hasrat dan keinginan mereka untuk mempelajari al-Quran. Datu Maula Husain sangat menghargai keinginan itu dan menyatakan sangat gembira apabila mereka juga dapat membaca al-Quran seperti dirinya. Akan tetapi Datu Maula Husain menjelaskan bahwa al-Quran adalah kalam Allah yang suci, ia adalah firman Tuhan pencipta alam semesta, dan bagi orang Islam al-Quran adalah kitab suci yang untuk mempelajarinya orang tersebut haruslah lebih dahulu mengucapkan dua kalimah syahadat dan menghafalnya di luar kepala (Ahmad, 2000:17).

Orang Ternate tidak keberatan dengan persyaratan yang diajukan Datu Maula Husain dan sejak itulah mereka mulai berbondong-bondong masuk Islam. Pengajian yang diselenggarakan oleh Datu Maula Husain makin marak di mana-mana dan pelajaran keislaman mulai menyerap lapisan bawah masyarakat Ternate. Berita pengislaman orang-orang Ternate melalui tilawah al-Quran dan pengajian-pengajian akhirnya sampai juga pada kalangan istana. Kaicil Marhum mulai mengundang Datu Maula Husain untuk suatu audensi di istana yang dihadiri para Bobato (suatu nama kolektif dari para kepala pemerintahan) dan pembesarpembesar kerajaan lainnya. Datu Maula Husain diminta untuk membacakan ayat-ayat suci alQuran yang dibawakannya dengan sangat bagus. Baginda sangat terkesan atas tilawah al-Quran oleh Datu Maula Husain dan dengan spontan baginda dengan diikuti oleh para bobato dan hadirin yang ada mengucapkan dua kalimat syahadat (beragama Islam) yang dipandu oleh Datu Maula Husain. Raja, bobato dan pembesar tinggi kerajaan resmi telah memeluk agama Islam. Tidak ada catatan yang memastikan kapan kalangan istana kesultanan Ternate memeluk Islam. Akan tetapi Kaicil Marhum memegang kekuasaan antara tahun 1465-1486. Mungkin sekitar tahun 1470 Kaicil Marhum telah beraudensi dengan Datu Maula Husain dan pada tahun itu juga Kaicil Marhum telah memeluk Islam (Ahmad, 2000:17).
Atas dasar pengajaran Islam yang diajarkan kepada sultan dan para pengikutnya, maka Datu Maula Husain bukan saja diangkat sebagai guru mengaji di kerajaan Ternate saat itu, tetapi sultan mengangkat beliau juga sebagai penasihat di kesultanan Ternate. Sasaran utama tugas penasihat adalah memberikan bimbingan pendidikan agama berupa ibadah syariat (akhirat) dan pendidikan pemerintahan, hal-hal keduniaan (dunia). Inilah yang ada dalam struktur susunan lembaga adat Ternate hingga sekarang. Dalam penyebutannya sering diistilahkan dengan bobato dunia dan bobato akhirat.

Bobato dunia adalah semua lembaga, badan dan jabatan yang berhubungan dengan urusan keduniaan yang bersifat politik, ekonomi, sosial buadaya dan pertahanan keamanan. Sedangkan dari segi spiritual dan urusan keagamaan ditangan oleh Jou Lebe (badan syara). Badan ini dikepalai oleh seorang yang menjabat sebagai Khadi. Anggoatanya terdiri dari para imam, khatib dan para staf pelaksana. Para pejabat di bidang keagamaan terdiri dari Khadi atau Qalem, yaitu pejabat tertinggi dalam urusan keagamaan, yang membawa empat orang imam kesultanan; imam Jiko, imam Jawa dan Melayu, imam Sangaji, imam Moti dan imam Bangsa.

Jabatan lainnya adalah para Khatib, yaitu pejabat pelaksana dakwah dan syariat Islam di bawah imam, terdapat enam jabatan Khatib dalam struktur kesultanan Ternate. Tiap Khatib membawahi beberapa orang modim (muazin). Keenam orang Khatib tersebut terdiri dari; Khatib Jiko, Khatib Jawa dan Melayu, Khatib Sangaji, Khatib Moti, Khatib Bangsa dan Khatib Juru Tulis (Syah, 2005:100-101).

Dengan demikian dapat dikatakan bahwa peranan orang Melayu dalam proses islamisasi di Ternate adalah berawal dari contoh yang ditampakkan oleh orang Melayu sendiri dalam penguasaan atas pengetahuan membaca alQuran itulah yang dipakai untuk mengajarkan agama Islam kepada masyarakat Ternate, dengan menjadikan mereka Islam. Ini berarti bahwa ada perbedaan dengan daerah-daerah lain dalam proses penerimaan agama Islam. Yang mana kalau di Ternate melalui para pedagang Islam kepada masyarakat dan kemudian baru dilanjutkan ke raja atau sultan.

Pranata-pranata Islam dipadukan dengan lembaga-lembaga adat dan tradisi rakyat. Adopsi paling mendasar atas institusi Islam adalah pergantian predian kolano (raja) dengan 
sultan. Tokoh yang harus disebut karena jasanya mentransformasikan Islam ke dalam kelembagaan kerajaan adalah Zainal Abidin, raja Ternate pertama yang menggantikan predikat kolano dengan sultan. Beliau adalah murid dari Sunan Ampel dan jebolan sekolah agama Islam Gresik asuhan wali yang terkenal itu. Ia adalah sultan Ternate pertama yang membentuk institusi Islam dalam struktur pimpinan tertinggi agama Islam di bawah sultan. Ia pula menciptakan lembaga baru dalam struktur pemerintahan, yaitu hukum bobato dengan tugas hakim sekaligus magistraat yang menjadi pembantu sultan. Dalam melaksanakan tugas-tugas keseharian sultan selalu dibantu oleh pembantu-pembantunya.

Gairah keislaman yang ditanamkan oleh Datu Maula Husein pada Zainal Abidin Syah terlihat nyata dengan antusiasnya sang sultan pertama menimba ilmu di pulau Jawa, tepatnya di Gresik pada Sunan Giri. Bahkan sekembali dari Jawa, sultan membawa beberapa ulama yang kemudian berdomisili di sebuah tempat di Ternate yang bernama Fala Jawa (rumah Jawa). Secara garis besar etnis yang mendiami Fala Jawa terdir dari orang Melayu, peranakan Arab dan Cina yang telah lama menjadi muslim. Peranan sultan Zainal Abidin tidak hanya sampai di sini, tetapi sultan Zainal Abidin juga mendirikan pendidikan sekolah agama dan mewajibkan pegawai daerah untuk belajar syariat Islam di Ternate (Puslitbang Lektur Keagamaan, 2010:80).

Zainal Abidin Syah adalah sultan yang ketika menduduki tahta kekuasaan menggantikan ayahnya; maka ada beberapa langkah yang dilakukannya tentang penyebaran dan permurnian atas Islam di Ternate. Pertama, sultan Zainal Abidin Syah yang menukar agama Jahiliyah kepada agama Islam di Ternate, dengan menggantikan jabatan Kolano dengan nama jabatan Islam yaitu sultan. Dan yang kedua adalah menginstruksikan kepada semua penduduk Ternate untuk bergaul dan berbusana sesuai dengan ajaran Islam. Dan yang ketiga adalah menjadikan agama Islam sebagai agama kerajaan untuk Ternate dan sekitarnya. Dan melalui tiga keputusannya itu, Sultan Zainal Abidin Syah berkata "agama Islam adalah agama yang benar maka saya telah masuk, dan akan mengabdikan diri kepada agama Islam". Inilah yang disebut sebagai penerimaan Islam oleh kesultanan Ternate secara resmi, atas jasa dan peranan dari orang Melayu.

Pengganti sultan Zainal Abidin Syah, adalah sultan Bayanullah. Di kalangan orang barat, ia dikenal dengan nama Abu Lais, atau sultan Boleif. Ia merupakan tokoh yang dipandang terpelajar. Pada masa kekuasaannya peradaban Islam (civilisasi Islam) diterapkan dalam pemerintahan kesultanan Ternate. Ia menyadari kelemahan-kelemahan rakyatnya pada umumnya. Sebagai terpelajar ia ingin memperbaikinya melalui langkah-langkah kongkrit dan strategis. Antara lain diterapkannya peraturan (regulasi) sejak tahun 1500 yang bertujuan untuk memperbaiki syariat Islam dalam 4 (empat) hal: 1) Pembatasan poligami, dimana rakyat Ternate, yang sudah beragama maupun belum, seperti yang dikeluhkan oleh Franciscus Xaverius, bahwa mereka tidak dapat hidup tanpa poligami. Sultan Bayanullah mengenakan sejumlah persyaratan berat. Sehingga secara formal hampir tidak ada celah lagi yang dapat membawa seseorang untuk berpoligami. 2) Larangan kumpul kebo dan pergundian. Kedua kebiasaan ini terutama dilakukan para bobato. Ada bobato yang memelihara gundik hingga puluhan orang. Sultan Bayanullah membuat peraturan; bobato yang memelihara gundik tanpa persetujuannya akan dipecat. Sampai akhir hayatnya, Bayanullah hanya hidup dengan seorang isteri, yaitu Nyai Cili Boki Raja Nukila putri Al-Mansyur sultan Tidore, dengan dua orang putera masing-masing Deyalo dan Boheyat. 3) Biaya dan peningset dalam perkawinan yang berlebihan dipangkas. Peningset yang memberatkan dan permintaan-permintaan dalam keluarga perempuan yang berlebihan dilarang. Ia menerapkan syarat "ijab-kabul" perkawinan baik hal itu dilakukan secara Islam maupun adat. 4) Perempuan wajib berpakaian secara pantas. Pemakaian "cidaku" atau cawat di kalangan laki-laki dilarang, yang ketahuan memakai cidaku akan dihukum (Amal, 2003:39).

\section{Bangunan Keagamaan Orang Melayu}

Peran orang Melayu di Ternate pada abad ke 15 dan 16 dalam bentuk bangunan keagamaan yang hingga sekarang masih terlihat adalah masjid sultan atau dalam bahasa lokal Ternate biasanya disebut "Sigi Lamo". Sigi terjemahan dari masjid, sedangkan Lamo maksudnya besar. Ada beberapa versi tentang lokasi dimana masjid ini dibangun. Dalam sebuah catatan yang ditulis oleh M. Adnan Amal, bahwa masjid agung ini dibangun dalam tiga tahapan.

Sigi Lamo (Masjid Agung) pertama dibangun ketika Portugis datang ke Ternate dan berhasil menjalin kerjasama dengan kesultanan Ternate, maka kepada orang Portugis diberikan kesempatan untuk membangun Benteng Gamlamo. Di dekat lokasi benteng itu telah berdiri sebuah masjid yang 
menjadi tempat shalat orang Ternate kala itu. Dan ini merupakan masjid pertama dalam masa kesultanan Ternate yang berbahan kayu.

Pada masa pemerintahan sultan Khaerun, Gubernur Portugis Antonio Galvao (1536-1540) meminta kepada sultan untuk memindahkan Sigi Lamo kira-kira 100 meter dari Benteng Gamlamo. Sultan Khaerun mengabulkan permintaan itu. Tidak ada keterangan mengapa orang Portugis enggan untuk berdekatan dengan Benteng Gamlamo dengan Masjid. Naman menurut peneliti bahwa kebijakan pemindahan masjid ini ke tempat yang agak jauh dari benteng karena faktor agama Islam. Dan di sisi yang lain yaitu agar komunitas Melayu yang Islam itu tidak lagi berdekatan dengan pusat perdagangan Ternate. Bila dibandingkan dengan kondisi kekinian untuk masjid yang dekat dengan Benteng Gamlamo adalah masjid an-Nur (masjid Cim), sekitar 50 meter, yang berada di kelurahan Kampung Makassar Barat. Sebelum datangnya Portugis dan Belanda orang Melayu telah membuat dan memiliki gudang yang merupakan tempat penyimpanan barang dagangan. Yang mana benteng ini tentunya dibangun oleh pedagang Melayu. Dengan demikian dapat dikatakan bahwa yang berperan dalam pembangunan Sigi Lamo (masjid agung) ini adalah orang Melayu. Alasannya karena pedagang Melayu itu adalah pedagang-pedagang Islam, yang tentunya menginginkan jarak antara tempat beribadah dan tempat dagangan itu tidak terlalu jauh.

Sigi Lamo yang kedua, adalah sekitar tahun 1550-an, Sultan Khaerun melakukan renovasi besar-besaran terhadap bangunan masjid pertama. Yang lokasinya sudah tidak lagi berdekatan dengan Benteng Gamlamo. Selain diperbesar, bahan bangunan masjid itu telah menggunakan batu untuk membuat dindingnya. Arsitektur masjid ini masih sama seperti masjid pertama hanya saja atap telah berubah menjadi tiga tumpang atau tiga susun. Setelah proses renovasi selesai maka sultan Khaerun membentuk badan pengurus masjid. Yang terdiri dari dua orang imam, empat orang khatib, dan empat belas moding. Tentunya jabatan pengurus masjid ini merupakan jabatan yang diwarisi oleh para pedagang Melayu, yang eksis di kota Ternate kala itu.

Sigi Lamo yang ketiga, adalah berdasarkan laporan yang dibuat oleh Wolter Schouten (Belanda), yang mengunjungi Ternate pada tahun 1659 menyatakan bahwa ia menemukan sebuah masjid besar satu-satunya yang ada di Kota Ternate, berdiri di tengah-tengah kampung Melayu. Masjid ini dengan berbentuk segi empat dengan atap lima tumpang. Melihat kolasi di mana masjid itu beridiri yakni di perkampungan orang Melayu, maka dapat ditarik kesimpulan bahwa masjid tersebut dibangun oleh orang Melayu. Masjid yang dibangun oleh orang Melayu serta kedaton kesultanan Ternate merupakan dua bangunan yang memberikan ciri khas kepada ibu kota kerajaan pada masa kekuasaan sultan Zainal Abidin Syah (Amal, 2009:9).

Salah satu bendera atau petaka kesultanan Ternate hingga saat ini pun masih terlihat. Pada bendera atau petaka terlihat huruf Arab berbahasa Melayu yang dapat dibaca. "Almulk Buldan Ternate" . Bendera ini untuk pertama kali digunakan oleh sultan Zainal Abidin Syah. Tentang siapa yang memprakarsai bendera yang menjadi ciri khas dari kesultanan Ternate tidak ada keterangan yang didapat.

\section{Budaya Melayu Dalam Tradisi Ternate}

Budaya Melayu yang mentradisikan di Ternate adalah fenomena kegiatan yang menjadi adat kebiasaan di Ternate yang bercirikan Islam. Yang mana dalam praktek kegiatan itu budaya lokal selalu dipadukan dengan budaya Islam. Untuk kejelasannya peneliti mengutip beberapa budaya yang sampai sekarang masih eksis. Tradisi-tradisi ini pada esensinya menampilkan sifat humanis dan sifat religius. Ciri dan nama dari adat dan kebiasaan itu menunjukan adanya elaborasi antara bahasa lokal dan bahasa Melayu ala Islam. Untuk lebih jelas peneliti mengutip enam tradisi yang ditulis oleh Amas Diense dan Rinto Thaib (Diense,2008:123).

\section{Adat Se Atorang}

Adat Se Atorang dapat dikonotasikan dengan kata "akhlakul karimah" dalam konteks doktrin ajaran agama Islam. Untuk memahami sejauh mana konsepsi Adat Se Atorang ini ditetapkan atau diimplementasikan dalam kehidupan rakyat (masyarakat lokal), masih eksis dalam realitas kehidupan masyarakat melalui berbagai corak aktifitas kehidupan sehari-hari. Salah satu contoh yaitu pakaian. Sebagai seseorang yang kebetulan dipercayakan memangku salah satu jabatan sebagai petugas syara di mesjid, pakaian sebagai imam tidak sama dengan pakaian seorang khatib atau modem.

\section{Galep Se Lakudi}

Galep Se Lakudi yang telah berakar pada masyarakat Ternate tidak lain adalah keterikatan 
manusia dengan lingkungan alam sekitarnya. Kepedulian terhadap lingkungan, membuat sultan Ternate memberikan hak kepemilikan tanah untuk dijaga dan dirawat oleh sekelompok orang. Pembagian lahan kepada kelompok masyarakat yang disebut bubula kaha. Pembagian tanah ini dibagi dalam tiga kategori; bubula Heku, bubula Cim, dan bubula Soa-Sio. Dalam sebuah syair:

Matubu Kie Raha, Lobi yo foti sio gaman, abu moju fo madike, guru-guru yo nga demo, bolo wasu ri pada mara, ngama ri moi kari nonako. Artinya puncaknya empat gunung, kabut menutup aduhai kelam, selagi hidup kita mencari, guru-guru punya ucapan, untuk menjadi pelitaku, sebuah bintang menjadi tanda. Maksudnya betapa pentingnya lingkungan pada manusia. Apabila manusia menjaga keanekaragam pesona alam lingkungan, maka manusia akan merasa betapa indahnya alam bagi kehidupan manusia.

\section{Cing Se Cingare}

Ini dimaksudkan bahwa masyarakat adat Ternate sadar akan nilai-nilai etika, moral dan kebersamaan yang menjadi dasar kerukunan hidup bermasyarakat. Sebagai contoh, bila ada seseorang yang berjalan di depan orang yang sedang duduk. Maka yang berjalan akan melakukan sebuah penghormatan dengan mengangkat kedua tangannya sambil berucap "suba Jou" artinya sujudku peruntukan padamu. Dan yang dihormati akan membalas dengan ucapan "Jou suba Jou". Sifat seperti ini tertuang dalam puisi rakyat yang berbunyi: Ino fo Makati nyinga, doka gosora se bua lawa, om doro fo ma nomote, fo ma gogoru foma dodara. Artinya mari kita bertimbang kasih seperti pala dengan fulinya, jatuh bangun kita bersama, berkasih mesra di antara kita.

\section{Baso Se Hormat}

Masyarakat adat Ternate dalam pergaulan sehari-hari di dalam kenyataannya lebih banyak menggunakan bahasa sapaan. Ini dimaksudkan agar terjadi keharmonisan dan ke akraban baik dalam lingkungan keluarga maupun dalam lingkungan masyarakat.

Salah satu contoh dari sifat ini terdapat pada puisi rakyat (dola bololo) yang berbunyi: Dara tolefo mampila, soro gudu to nonako, gudu moju si to suba, ri jou situ nonako. Artinya; burung merpati kuberi tanda, terbang jauh aku kenali, masih jauh sudah kuberi hormat tuanku maku sudah ku kenali.

\section{Baso Se Rasai}

Ketika terdengar istilah duduk sama rendah, atau berat sama dipikul ringan sama dijinjing, maka itulah yang disebut baso se rasai oleh masyarakat Ternate. Baso se rasai mengandung makna toleransi spiritual, yaitu sikap manusia yang manusiawi. Hal ini tertuang dalam sebuah puisi rakyat:

Ngoni doka dai lako, ahu ma fara-fara, si rubu-rubu yo mamoi-moi, doka saya rako moi. Artinya kita bagaikan kembang tumbuh hidup berpencar, tersimpun dalam satu genggaman, bagaikan serangkai kembang. Prinsip-prinsip baso se rasai sangat relevan dengan ajaran Islam. Oleh karena itu, jika nilai-nilai baso se rasai ditanamkan dalam pergaulan hidup maka akan terciptalah kemakmuran hidup.

\section{Duka Se Cinta}

Duka se cinta mengandung makna mengenang atau turut merasakan penderitaan yang dialami oleh seseorang. Duka se cinta yang telah ditanamkan sejak dulu, mengandung nilai dan pesan moral serta memiliki makna religius yang cukup tinggi terutama bagi keharmonisan masyarakat yang beragama Islam.

Pesan ini terungkap dalam sebuah syair eli-eli sosou nginga demo madero, afa mara cobo sala demo kanang. Beberapa contoh dari produk hukum adat yang bisa dipraktekkan sama baik oleh kalangan istana maupun masyarakat luas di luar istana selain yang disebutkan di atas adalah adat warisan para leluhur yaitu joko kaha, kololi kie, dan fere kie (Diense, 2008:80-90).

Dapat penulis sampaikan bahwa mengapa orang Melayu di Makassar sangat banyak berhasil dalam menjalin kerjasama dengan orang Makassar, karena raja Makassar tidak pernah diajak kompromi oleh orang Portugis maupun orang Belanda. Orang Portugis dan Belanda tidak pernah diberikan kesempatan untuk campur tangan dalam hal-hal kerajaan Makassar. Sehingga begitu banyaknya peranan orang Melayu di Makassar sangat besar. Raja Makassar pun memberikan tugas-tugas ekonomi, politik pendidikan dan perdagangan kepada orang Melayu. Dan begitu eratnya hubungan orang Melayu dengan kerajaan Makassar. Dengan demikian informasi tentang orang Melayu berupa data-data tertulis sangat banyak. Selain itu komunitas orang Melayu pun hingga sekarang masih ada di Makassar.

Hal seperti ini tidak berlaku di kerajaan kesultanan Ternate. Olehnya itu data dan informasi tertulis tentang orang Melayu di Ternate sangat terbatas. Nyaris, data dan bukti berupa bangunan atau tempat pemukiman orang Melayu pun 
tidak ada. Satu-satunya benteng yang dulunya merupakan gudang para pedagang Melayu telah berubah menjadi benteng milik orang Portugis dan kemudian Belanda. Saat Portugis berhasil dalam penyebaran agama Kristen dan berhasil pula terlibat dalam kebijakan-kebijakan kesultanan Ternate. Keberhasilan Portugis bukan saja dalam penguasaan atas rempah-rempah, turut campur tangan pengambilan kebijakan di kesultatan Ternate, berhasil menyebarkan agama Kristen. Dan ini berlaku pula ketika Belanda masuk di kota Ternate. Belanda berhasil untuk menjalin kerja sama dengan kesultanan Ternate, lalu kemudian Belanda mengambil beberapa kebijakan yang semestinya merugikan kesultanan Ternate, dan para pedagang Melayu pun terkena dampak kebijakan itu.

Andaikan bukan Nahkoda Ismail yang orang Melayu itu menjadi penunjuk jalan ke Ternate, mungkinkah pedagang Eropa akan sulit atau bahkan tidak menemukan kepulauan rempah-rempah. Tetapi tanpa Nahkoda Ismail pun pedagang Eropa akan menemukan Ternate. Dengan demikian pada sisi perdagangan Nahkoda Ismail menjadi tokoh dalam menemukan Ternate. Dan dari segi penyebaran agama Islam Datu Maula Husein merupakan tokoh Melayu yang sangat gesit dalam membumikan Islam di Ternate. Namun perlu diketengahkan pula bahwa selain orang Melayu, adapula pedagang Arab, yang mana mereka juga mempunyai peranan dalam penyebaran Islam. Dengan demikian corak keberagamaan yang sekarang dianut oleh masyarakat Maluku Utara (Ternate) adalah merupakan saluran Islam yang di bawah oleh pedagang Melayu.

\section{PENUTUP}

Datuk Maula Husain sebagai orang Melayu yang sangat berperan dalam proses masuk dan berkembangnya Islam di Ternate. Beliau mempunyai suara yang merdu dalam membaca al-Quran sehingga orang Ternate ingin untuk mengikutinya. Dan diundang oleh sultan Ternate untuk mengajarkan baca-tulis al-Quran kepada orang-orang yang ada di kesultanan Ternate. Masjid kesultanan Ternate merupakan masjid yang dibangun oleh orang Melayu. Dikatakan demikian karena masjid ini berada di kampung Melayu, berdekatan dengan gudang para pedagang Melayu. Masjid ini oleh penduduk setempat biasanya disebut masjid sigi lamo artinya masjid besar. Ekstensi masjid ini bertepatan dengan masa kekuasaan sultan Zainal Abidin Syah tahun 1486-1500.

\section{UCAPAN TERIMA KASIH}

Hasil penelitian secara niscaya masih perlu penyempurnaan. Penelitian yang sama perlu dibahas dibagian lain untuk pengungkapan tentang sejarah Ternate lebih dalam lagi. Namun, di atas kekurangan dari penelitian ini penulis ucapakan terima kasih kepada informan dan semua pihak yang telah memberi masukan atas penelitian ini. Dan terima kasih kepada Tim Redaksi jurnal AlQalam yang telah memberi kesempatan untuk terbitnya tulisan ini.

\section{DAFTAR PUSTAKA}

Abdurrahman, M. Jusuf et.al. 2001. Ternate Bandar Jalur Sutera. Ternate: Lintas.

Ahmad, Kasman dkk. 2000. Damai yang Terkoyak Catatan Kelam Dari Bumi Halmahera, Ternate: Manadi Press.

Ambari, Hasan Muarif. 1998. Menemukan Peradaban Jejak Arkeologis dan Historis Islam Indonesia. Jakarta: Logos.

Amal, M. Adnan. 2009. Kepulauan Rempah-Rempah Perjalanan Sejarah Maluku Utara 1250-1950. Makassar: Bakti.

Amal, M. Adnan \& Irza Arnyta Djafar. 2003. Maluku Utara Perjalanan Sejarah 1800-1950, Unkhaer:Ternate.

Diense, Amas H. \& Rinto Thaib. 2008. Ternate (Sejarah Kebudayaan \& Pembangunan Perdamaian Maluku Utara) sosil. Ternate: Lekra-MKR.

Hanafiah, Johan. 1995. Melayu-Jawa Citra Budaya \& Sejarah Palembang. Jakarta: Raja Grafindo.

Sjah, H. Mudaffar. et.al. 2005. Moloku Kie Raha Dalam Perspektif Budaya \& Sejarah Masuknya Islam. Ternate: HPMT Press.

Nomay, Usman. 2009. Orang Melayu di Makassar Abad XVI-XVII. Makassar: Raihan.

Pelly, Usman. 1994. Urbanisasi dan Adaptasi Peranan Misi Budaya Minangkabau dan Maidaling. Jakarta: LP3ES.

Puslitbang Lektur Keagamaan. 2010. Sejarah Sosial Kesultanan Ternate;Jurnal Lektur Keagamaan. Jakarta: Badan Litbang \& Diklat, Kementerian Agama RI.

Kementerian Agama RI Badan Litbang dan Diklat Puslitbang Lektur Keagamaan. 2010. Sejarah Sosial Kesultanan Ternate. Jakarta.

Wallace, Alfred Russel. 2009. Kepulauan Nusantara Sebuah Kisah Perjalanan, Kajian Manusia dan Alam. Jakarta: Kumunitas Bambu. 